\title{
Teacher Preparedness in Implementing Inclusive Education for Pupils with Hearing Impairments in Mombasa County, Kenya
}

\author{
${ }^{1}$ Mr. Hassan Luvanga ${ }^{*}{ }^{2}$ Dr. Sarah W. Mwangi, ${ }^{3}$ Dr Robert J. Maneno \\ ${ }^{1} \mathrm{PhD}$ student in Department of Educational Psychology and Special Needs Education, \\ Pwani University, P. 0 B0X 195-80108, Kilifi, Kenya \\ ${ }^{2}$ Department of Educational Psychology and Special Needs Education, \\ Pwani University, P. 0 B0X 195-80108, Kilifi, Kenya \\ ${ }^{3}$ Department of Educational Psychology and Special Needs Education, \\ Pwani University, P. 0 B0X 195-80108, Kilifi, Kenya
}

\begin{abstract}
Inclusion is a philosophy that focuses on the process of adjusting the home, school and the larger society to accommodate persons with special needs. The success of provision of inclusive practices is contingent upon the quality of teaching in an inclusive setting. This study was conducted in Mombasa County, Kenya. The study investigated teacher preparedness in the implementation of special needs inclusive education in primary schools with pupils with hearing impairments. The study focused on teachers' academic qualifications, professional qualifications, teaching experience and whether the teachers had undertaken pre- service or in-service special education training. The target population was 60 teachers and 20 head teachers teaching in schools with pupils with hearing impairments. The findings revealed that although most teachers had the necessary academic qualifications to teach pupils in primary schools, they lacked adequate special education training to effectively teach pupils with hearing impairment and majority of the teachers had not undertaken any pre-service or in-service special education training. Recommendations suggested that teachers should be adequately prepared during their pre-service education programme to effectively teach pupils with hearing impairments within the mainstream classroom settings. Teachers need also to enhance their special education skills through in-service special education training.
\end{abstract}

Keywords: Inclusive Education, Hearing Impairments, Inclusive strategies, primary school, pupil, county

\section{Introduction}

Inclusion is a philosophy that focuses on adjusting the home, school and the larger society to accommodate persons with special needs including disability (Alquraini, \& Gut, 2012). The philosophy advocates that all individuals regardless of their differences be accorded the opportunity to interact, play, learn, work and experience the feeling of belonging. For this to happen, teachers, schools, and education systems need to modify the physical and social environment so that they can adequately accommodate learners' diversity (KISE, 2007).

Hearing impairment is a hidden disability because it is not clearly identifiable. HI or deafness according to Rosa, Somido, Bermudo, Salinas, Yango \& Galicia, (2017) is a condition where an individual is impaired in processing linguistic information through hearing. The severity of a hearing impairment is measured by the amount of sound that can be heard using one's better ear and this is measured using decibels (dB). Hearing loss can be caused by a number of factors including; heredity, aging, loud sound exposure, diseases and infections, trauma, or ototoxic drugs (Lash, 2011). Statistics from the World Health Organization (2012) reveal that 120 million people globally live with hearing impairment. In Sub Saharan Africa, there are about 1.2 million children aged between 5- 14 years old who are suffering from moderate to severe hearing loss.

According to the Kenya National Bureau of Statistics (2010), out of the country's population of 38.7 million, 800,000 live with hearing impairments. The number of primary school children in Kenya living with hearing impairments is considered to be a fifth of the population living with hearing impairments in 
Kenya and the number is rising due to different array of factors caused by high levels of poverty in some areas. Kenya has taken steps to formulate legislation and policies with a view of attaining nationwide inclusive education (Republic of Kenya, 2009). The Persons with Disabilities Act (2003) Section 18, prohibits discrimination against children with disabilities in accessing education institutions by virtue of their disability $(\mathrm{GoK}, 2003)$. The Act further provides for the establishment of special institutions. However, the Act fails to mention to who the responsibility of this right is to be achieved. The Act does not place the obligation to realize this right on the state but emphasizes the rights of persons with disabilities and inclusion at the top of the agenda. The key instrument in achieving nationwide inclusive education is the 2009 Special Needs Education Policy Framework (Republic of Kenya, 2010). The Ministry of Education in partnership with various stakeholders ensured that there is a guiding document that would help pupils with disabilities receive equal access to special education services and further boost the country's goal of achieving Education for All. Some of the objectives of the Special Needs Education Policy framework include assessment and intervention, advocacy and awareness creation, capacity building and development, research and documentation, and use of specialized facilities and technology. Inclusion is a contemporary pertinent issue that Kenya as a country and the county of Mombasa in particular is in the process of embracing as an innovation to integration. The key instrument in achieving nationwide inclusive education is Special Needs Education Policy Framework (Republic of Kenya, 2010).

\section{Purpose of the Study}

The purpose of this study was to investigate teacher preparedness in implementing special needs inclusive practices for learners with hearing impairments in public primary schools in Mombasa County, Kenya.

\section{Study Objectives}

- To determine the academic and professional preparedness of teachers in primary schools with pupils with hearing impairments in Mombasa County, Kenya.

- To verify the teachers experience in teaching pupils with hearing impairments in Mombasa County, Kenya.

- To find out whether teachers had any special education training in the area of hearing Impairments.

\section{Research Design And Methodology}

\section{Methodology}

This study adopted a descriptive survey research design. Descriptive survey designs are used in preliminary and exploratory studies so as to allow the researcher to gather information, summarize, present and interpret the study for the purpose of clarification (Orodho, 2012). The researchers opted to gather both qualitative and quantitative data. The purpose of the quantitative data was to get statistical data on teacher preparedness while qualitative data was able to bring a deeper understanding on the reason as to why the statistics are as shown by the quantitative data.

\section{Study participants, sampling criteria and sample size}

The target population comprised of two hundred and ten (210) teachers and twenty (20) head teachers from twenty (20) public primary schools in Mombasa County implementing inclusive education for pupils with hearing impairments. Teachers were selected for this study because they are the major agents in the implementation of inclusive education practices for pupils with hearing impairment. Teachers are also in direct contact with pupils with hearing impairment in public primary schools and hence, their responsibility in implementing special needs education inclusive practices in schools. The sample size for the study comprised 60 teachers and 20 head teachers. To ensure that all teachers had an equal and independent chance of being selected as members of the sample, simple random sampling technique was employed.

\section{Results And Discussion}

\section{Teachers' Academic Qualifications}

In total 60 teachers completed the questionnaires that were administered and gave their academic qualifications as stated in Table 1 
Table 1: Academic Qualifications of the Teachers

\begin{tabular}{|l|l|l|}
\hline Academic Qualification & Frequency & Percentage \\
\hline K.C.E/K.C.S.E & 54 & 90 \\
\hline E.A.C.E/K.A.C.E & 6 & 10 \\
\hline Total & 60 & 100 \\
\hline
\end{tabular}

From table 1, it can be noted that 54 teachers (90\%) were Kenya Certificate of Secondary Education (KCSE) holders and $6(10 \%)$ were Kenya Advanced Certificate of Education (KACE) holders. The implication of the findings is that most of the teachers implementing special needs inclusive practices had the necessary academic qualifications to teach pupils with hearing impairments. Conversely, the head-teachers' questionnaires established that fourteen of the head-teachers (70\%) were Kenya Certificate of Secondary Education (KCSE) holders while six (30\%) were Kenya Advanced Certificate of Education (KACE) holders. The results indicated that most of the head-teachers had the necessary academic competencies and hence, they were likely to offer the required academic guidance to their teachers given their high academic qualification. This is consistent with findings by Oosero (2015) who notes that widespread involvement of teachers in curriculum implementation is effective only under qualified leadership. Head-teachers who are academically sound are likely to motivate special education teachers to undertake teacher development programmes like in-service special education courses to enhance their teaching practices.

\section{Teacher's Professional Qualifications}

The 60 teachers implementing special needs inclusive practices for pupils with HI to whom the questionnaire was administered gave their professional qualifications as shown in Table 3.

Table 2: Professional Qualification of the Teachers

\begin{tabular}{|l|l|}
\hline Highest Professional Qualification & No. of Teachers \\
\hline Certificate in Primary Education & 42 \\
\hline Diploma in Special Needs Education & 12 \\
\hline B Ed in Special Needs Education & 6 \\
\hline Total & 60 \\
\hline
\end{tabular}

From Table 2, it can be observed that out of the 60 teachers implementing special needs inclusive practices for pupils with hearing impairments, $42(70 \%)$ had Certificate in Primary Education(CPE) with no specialization in special education, $12(20 \%)$ were Diploma holders in Special Needs Education and only six $(10 \%)$ held a Bachelors degree in Special Needs Education. From this it can be inferred that majority of the teachers did not have a background in Special Needs Education. Consequently, there were inadequately prepared teachers to teach pupils with hearing impairment in public primary schools. Adoyo (2007) posits that in Kenya, teachers of pupils with hearing impairment need to understand the various modes of communicating and teaching learners with Hearing Impairments and hence should possess a Degree or Diploma in the area of Hearing Impairments.

\section{Teaching Experience}

In the questionnaire, teachers were asked to state the number of years they had taught pupils with HI. Table 3 shows the teachers' years of experience in teaching pupils with HI. 
Table 3: Teaching experience in teaching pupils with $\mathrm{HI}$

\begin{tabular}{|l|l|l|}
\hline Years in teaching pupils with HI & Frequency & Percentage \\
\hline Below 5 & 11 & 18 \\
\hline $6-10$ & 36 & 60 \\
\hline $11-15$ & 5 & 10 \\
\hline $16-20$ & 2 & 3 \\
\hline 21 and above & 5 & 8. \\
\hline Total & $\mathbf{6 0}$ & $\mathbf{1 0 0}$ \\
\hline
\end{tabular}

From Table 3, it can be noted that majority of the respondents had a teaching experience of below 10 years (78\%). The implication here is that these respondents cannot adequately and effectively interpret and implement special needs education inclusive practices curriculum for pupils with hearing impairments due to insufficient experience. According to Opertti et al (2013), teachers who have been implementing inclusive programmes, and have active experience of inclusion, possess more positive attitudes and show the great productivity gains in their teaching. In reference to this discourse, teaching experience is an important consideration in the inclusion of pupils with hearing impairment. This is because teachers often report a lack of knowledge and skills as a factor impeding their ability to successfully include pupils with hearing impairment in their classes (Ostrove \& Olivia, 2010). Inexperienced teachers cannot adequately and effectively interpret and implement special needs education inclusive practices for pupils with hearing impairments.

\subsection{Training in the area of Hearing Impairments}

Teachers were asked if they had undertaken any pre- service or in-service training in the area of Hearing Impairments. Findings indicated that six teachers $(10 \%)$ had undertaken some training in HI while the majority 54 (90\%) had not gone through any training in HI. Teacher training in HI is an important prerequisite for the inclusion of pupils with hearing impairment in regular schools. Lancaster and Bain (2010) state that pre-service and in-service teacher education programme are important agents for the implementation of inclusive education for individuals with HI. With the increasing inclusion of pupils with special needs in main stream classes, it has become essential to create 'pathways' for training teachers in special education to enhance their skills in teaching more diverse groups of pupils. The study findings were consistent with a study by Li, Oneonta \& Ji (2010) which revealed that although pre-service and in- service teacher education programmes in some parts of the United States and China had favourable attitudes towards inclusion, the teachers were inadequately prepared to teach pupils with Special Needs.

\section{Conclusion}

From the foregoing findings of the study, preparedness of teachers of pupils with HI in Mombasa County is wanting. To embrace the appropriate inclusive practices, there is need for the teachers to gear their professional qualifications towards meeting the unique needs of pupils with hearing impairments.

\section{Recommendations}

- The Ministry of Education in Kenya should ensure that teachers are adequately prepared during their preservice teacher training education programme to enable them to effectively teach pupils with Hearing Impairments within the mainstream classroom setting.

- The Ministry of Education in Kenya should ensure regular in-service special Education training for all teachers implementing special needs inclusive practices. This would keep them abreast with strategies and methods of teaching various categories of disabled pupils within an inclusive classroom setting.

- The Kenya Government should formulate clear policies and legislation to promote inclusive education for learners with Hearing Impairment.

\section{Declaration of Conflicting Interests}

The authors declared no potential conflicts of interest with respect to the research, authorship, and/or publication of this article 


\section{References}

[1.] Adoyo, P. O., \& Odeny, M. L. (2015). Emergent inclusive education practice in Kenya, Challenges

[2.] disabilities: Literature review. International Journal of Special Education, 27(1), 42-59.

[3.] GoK (2003). The Persons with Disabilities Act. Government Printer: Nairobi

[4.] Kenya Institute of Special Education (2007). Introduction to inclusive education. Module 10.

[5.] KNBS (2010). Kenya 2009 population and housing census results. Government Printer: Nairobi.

[6.] Lancaster, J., \& Bain, A. (2010). The design of pre-service inclusive education courses and their effects on self-efficacy: a comparative study. Asia-Pacific Journal of Teacher Education, 38 (2), 117-128. and suggestions. International Journal, 47.

[7.] Alquraini, T., \& Gut, D. (2012). Critical components of successful inclusion of students with severe

[8.] Lash, B. N. (2011). Deaf or Hearing: A Hearing impaired individual's navigation between two worlds.

[9.] Li, D. Oneonta, S., \& Ji, H. (2010). Teaching students with disabilities in regular education classes: Perceptions of pre-service teachers from China and United States. Educational Research and Development, 13 (1), 62-69.

[10.] Mugenda, O. M., \& Mugenda, A. G. (2012). Research methods dictionary.

[11.] Orodho, A. J. (2012). Techniques of Writing Proposals and Research Reports in Education and Social Science Research Methods: Maseno. Kenya: Kanezja Publishers.

[12.] Oosero, P. O. (2015). Challenges Teachers Encounter In Implementing Inclusive Education In Public Primary Schools In Nyamira County, Kenya. International Journal for Innovation Education and Research, 3(3).

[13.] Ostrove, J., \& Olivia, G. (2010). Identifying allies: Explorations of deaf-hearing relationships. In S. Burch \& A. Kafer (Eds.), Deaf and disability studies: Interdisciplinary perspectives (pp. 105-119). Washington, D.C.: Gallaudet University Press.

[14.] Republic of Kenya. (2010). The National Special Needs Education Policy Framework. Nairobi, Kenya: MOE

[15.] Rosa, R. M. D., Somido, F. C., Bermudo, P. J. V., Salinas, E. A., Yango, A. R., \& Galicia,L.S. (2017). Never Deaf of Learning with Heart: Understanding the Essence of Handling Pupils with Hearing Impairment. Journal of Social Sciences (COES\&RJ-JSS), 6(4), 726-733.

[16.] SAHI. (2011).Prevalence of Hearing Loss.

[17.] WHO (2012).WHO global estimates on prevalence of hearing loss. 